DOI: https://doi.org/10.47405/aswj.v6i2.166

\begin{tabular}{|c|c|}
\hline & Asian Social Work Journal (ASWJ) \\
$\substack{\text { ASIAN SOCIAL WORK } \\
\text { JOURAL } \\
\text { (ASW) }}$ & Volume 6, Issue 2, April 2021 \\
& e-ISSN : 0128-1577 \\
& Journal home page: \\
& www.msocialwork.com \\
\hline
\end{tabular}

\title{
A Case Study of the Management of the Private Shelter for Unmarried Pregnant Adolescents
}

\author{
Fuziah Shaffie', Mohamad Shahbani Sekh Bidin'1, Md Zawawi Abu Bakar' \\ ${ }^{1}$ School of Applied Psychology, Social Work and Policy (SAPSP), College of Arts and Sciences \\ Universiti Utara Malaysia, Kedah, Malaysia \\ Correspondence: Mohamad Shahbani Sekh Bidin (mohamad.shahbani@gmail.com)
}

\begin{abstract}
In Malaysia, one of the most worrying issues for the community, especially parents is the case of unmarried pregnant among adolescents. However, few parents and members of the community are truly sensitive to the threat of this social problem. Various efforts are being made by the government and nongovernment agencies to help these adolescents to reduce the problem. One of them is to create temporary shelters to guide and help the adolescents to move forward with their lives towards a more positive path. Nevertheless, these efforts can either have a positive or negative impact on the adolescents involved if the shelters are not properly managed. This qualitative study was conducted to explore aspects of management in a shelter set up specifically for unmarried pregnant adolescents. The results of the interviews with the shelter operator were transcribed fully before being analyzed thematically. The results of the study found that the nature of wanting to help and high perseverance had prompted the operator to set up a shelter specifically for unmarried pregnant adolescents. The shelter was found to gain strong social support. Among the support provided is from individuals or groups which include free academic teaching, food supply, daily necessities, finance for utilities, in addition to the creation of a comfortable physical environment. The operator also used social networks such as close friends to help manage the residents at the shelter. In addition, social media was also utilized by the operator so that many individuals provide assistance to maintain the management of the shelter. This study contributes to the management of shelter for adolescent girls especially unmarried pregnant adolescents.
\end{abstract}

Keywords: shelter home, management, adolescents, unmarried pregnancy

\section{Introduction}

In the human developmental phase, the adolescent stage is a period of transition full of trials for an individual (Santrock, 2008; Steinberg, 2007). This sudden physical and physiological development makes adolescents confused. At this stage, their social preferences change and they will probably get caught up in unsafe sexual relationships resulting in extramarital pregnancies. This unmarried pregnancy is a social problem in most developed countries as well as developing countries. This phenomenon is now increasingly worrying and becoming an issue of the global community (Aishah, Najibah, \& Roslina, 2019; Fauziah, 2014). Based on the World Health Organization (WHO) report, for pregnancy cases involving adolescents aged between 15 to 19 years from 2005 to 2011, Malaysia is in fourth place out of 10 countries (Siti Marziah \& Nur Afifah, 2017). As reported by the Ministry of Health Malaysia (MOH), 
DOI: https://doi.org/10.47405/aswj.v6i2.166

the percentage of adolescents who became pregnant out of wedlock in 2014 was only $25 \%$, but had increased to $28.8 \%$ in 2015 (Malaysia Parliament, 2016).

If not well regulated, the issue of unmarried pregnancies can trigger other problems that may be worse such as unsafe abortions (Sedgh, Finer, Bankole, Eilers, \& Singh, 2015; Mohd Hatta, Kathryn, Faizah, Joanita, \& Norzawati, 2019), infant abandonment (Aishah et al., 2019; Nazni, et al., 2012) and illegitimate childbirth (Mohd Azis, 2010; Nor Jana, Dufaker, Eriksson, \& Ghazinour, 2013). Additionally, unmarried pregnancy is an illegal act and should not be accepted at all by the Malaysian society especially for those who are Muslims (Norhasmah, 2016; Rohany et al., 2016). Thus, most adolescents who get pregnant out of wedlock will feel more afraid to continue living due to feelings of shame and embarrassment, left by parents and friends. Such feelings can make them act recklessly to abort or discard the baby (Makiah Tussaripah et al., 2012; Wan Fadhilah, 2011). According to Harlina (2014), the number of unsafe or illegal abortions was found to increase by $30 \%$ due to the increase in unmarried pregnancy among adolescents. As for cases of abortion due to unmarried pregnancies, there have been more than 900 cases reported since 2005 (Royal Malaysian Police [PDRM], 2016). Since these problems are interrelated, then, the existence of the issue of unmarried pregnant adolescents can pose a big problem to society and the government if it is not curbed properly.

These social problems are also associated with various health and psychosocial problems of the individuals involved and the society (Sheela, Nair \& Rema, 2013; Mohamad Shahbani \& Fuziah, 2020). A review of past studies shows most of these out-of-wedlock pregnant adolescents are more likely to experience trauma and stress (Cense \& Ganzevoort, 2018; Pollock, 2016; Sedgh et al., 2015), have low self-esteem (Babington, Malone, \& Kelley, 2015), lack of ability to solve problems, have trust problems in the context of relationships as an adult and the life of a adolescent mother full of dangers and difficulties, lack of attention to antenatal care, hypertension due to pregnancy, pre-elampsia and premature birth (Coleman, 2006; Ghose, \& John, 2013), in addition to increasing the risk of death during childbirth (Vin et al., 2014). This sexual activity can lead to adverse consequences such as sexually transmitted diseases or HIV (Hultstrand, Tydén, Jonsson, \& Målqvist, 2019; Mohamad Faizal \& Mohd Zaki, 2014). In addition, these unmarried pregnant adolescents will be more likely to change schools, isolate themselves, be prone to drug abuse and repeated pregnancies (Fatimah, 2009; Hultstrand et al, 2019; Norhasmah, 2016). Some adolescents who get pregnant out of wedlock act more drastically such as dropping out of school to hide their pregnancies from the public. Such actions can limit employment opportunities. Thus it can also affect their financial capabilities in the future (Nor Jana et al., 2013). These conditions can make them suffer from socio-economic problems and have low self-esteem due to lack of knowledge and guidance to help them deal with the complex problems they are facing.

Pregnancy can be a bitter experience that can change a person's life. This bitterness, either from a psychological or social aspect, will be more severe if it occurs outside of marriage (Yahaya, Nor Firdaos, Normah, \& Shah Ezzat, 2007) and there are among them who are said to be unprepared or not planning to conceive. When confirmed pregnant, they will begin to be possessed by a high level of anxiety. This intense anxiety can make it difficult for them to face life's challenges (Azmawaty, Shanina Sharatol, Usharani, \& Zaida, 2019). Difficulties like these cannot be allowed to linger because the latency of such feelings can have a profound effect on the body and mind. Therefore, various efforts should be considered to help adolescents who are in this situation. One of the noble endeavours that is thought to be very good and relevant is to provide shelter for them.

\section{Shelter}

The increase and severity of social problems among these unmarried pregnant adolescents makes the individuals or groups feel that they really need strong social support (Khairul Hamimah, \& Nurul Husna, 2019). Thus, there are institutions, rehabilitation centres and shelters as a care effort that is expected to reduce their burden (Fuziah, 2016). In shelters, programs are arranged to provide appropriate guidance so that when they leave the shelters, they can return to the community successfully (Siti Marziah \& Nur Afifah, 2017). The shelter will provide transit space for older teens. They are taken care of as perfectly as possible until the end of childbirth. Apart from privately established, shelters are also set up by the 
DOI: https://doi.org/10.47405/aswj.v6i2.166

government and non-governmental organizations (NGOs) (Noor Hafizah, 2016). A shelter is basically ensured to be a safe and comfortable place for its occupants. The services provided by the shelters will usually be related to enhancement of spiritual and psychosocial strength in addition to motivational programs, takzirah and daily routines (Azizi, Yow Kiaw, \& Amir Hamzah, 2008; Noor Hafizah, 2016).

The establishment of shelter homes aims to help adolescents who are pregnant out of wedlock to be able to continue a good and happy life in the future (Azizi et al, 2008; Nurul Husna, Khairul Hamimah, Raihanah, \& Fakhrul Adabi, 2017). However, managing shelter homes is not an easy task. The challenges and constraints faced while managing it require tenacity and a high degree of patience. The shelter operators also need to always be open-minded to help these teens overcome their psychosocial problems. Every shelter needs to be managed wisely to ensure it remains relevant and lasts a long time (Fuziah, 2016; Khairul Hamimah, \& Nurul Husna, 2019). Each of these shelter operators needs to has his or her own method or strategy to ensure that the established shelter is "alive". Thus, the purpose of this current study is to gather information and analyze the characteristics or ways of managing these shelters. This study was conducted in a shelter, known as Rumah Cahaya (House of Light), to explore the management of the house, which managed to survive for a considerable time as well as achieve the goal of reducing the problem of out-of-wedlock teenage pregnancy. The information obtained was used to build a preliminary model of shelter management based on the methods practiced by the shelter operator. Successfully practiced management methods or strategies can serve as an example and reference to other individuals who want to help and support adolescents in dealing with social problems they are facing.

\section{Methodology}

This qualitative study used case studies to obtain information on programs conducted in a shelter in the central zone of Peninsular Malaysia. The shelter or house was purposively selected (Creswell \& Creswell, 2018). Qualitative data collection was done through a semi-structured in-depth interview with the operator of a shelter for unmarried pregnant adolescents. The respondent of this study (shelter home operator) was selected because she had full information on the matter to be investigated (Patton, 2002; Yin, 2003). The semi-structured in-depth interview method was chosen because it allows further study or follow-up to be made based on the answers given to the questions posed during previous interviews. The interview session was audio recorded. This action was taken as it allows the psychosocial phenomena of unmarried pregnant adolescents to be studied in detail (Creswell \& Creswell, 2018). Research ethics is adhered to by making in advance the request for permission to enter the research site and also obtaining consent of the respondent to be involved in the study. Consent forms for participation in the study as respondent and informant were provided. The research participant was also assured that all information obtained would be kept confidential and the real name will not be mentioned in the report. The agreement to participate also included the permission to write the research report, including in the form of empirical papers written based on this study. In addition, the researchers also informed the research participant that all the audio recordings will not be disseminated via the media and will only be used for the purpose of this research.

\section{Research Instrument}

The in-depth interviews with the shelter home operator was carried out based the questions within an interview guide that was specifically developed for this study. This semi-structured interview was a fundamental process that provided knowledge of a social world constructed through normal human interaction (Creswell, 2012; Yin, 2003). The interview session can be said to be retrospective in nature. Notably, the researchers (interviewers) too were the research instrument in this study since the data collected from the interviews very much depended on the questions asked and probed by the interviewers. Thus, these interviews were conducted face-to-face with the shelter operator. Questions for the interview sessions were constructed based on literature and experts' evaluation which comprised of psychologists, social experts, as well as religious experts. The evaluation session with the selected experts was carried in the form of a roundtable discussion and knowledge sharing approach. The experts evaluated the 
DOI: https://doi.org/10.47405/aswj.v6i2.166

questions and submitted their feedback and proposes changes to be made to the questions. Feedback on the questions is included in the interview guide. Example of the interview questions are as follows:

i. What is the background of this shelter?

ii. How do employers feel when operating this shelter?

iii. What facilities are available to residents?

iv. What are the supportive aids from the local community?

v. What are the issues or problems encountered in operating this shelter?

The information obtained through the interviews was directed to understand the perspective of the informant (shelter operator) about their life experience or situation as expressed in her own words. The interview data was analysed thematically (Braun \& Clarke, 2006). Thematic analysis provides space for interpretation and researcher's engagement and focuses on the production of themes (Marshall \& Rossman, 2010). The results of this qualitative data analysis became a meaningful input for the construction of a preliminary model of shelter management in this study.

\section{Research Findings}

The Rumah Cahaya (RC) profile is presented below. In addition, the presentation of the findings is also focus on aspects of RC management that point to the themes, (1) Establishment of Committees, (2) Psychosocial Support of Residents, (3) Health Care of Residents, (4) Safety of Residents, (5) Financial Contribution, (6) Promotion and Announcement, (7) Sponsorship, (8) Entrepreneur Communication Skills, (9) Valuing People, (10) Learning and Skills to Residents, and (11) Relationships with Resident Heirs. Next, a preliminary model to describe management by RC operator was constructed based on the themes obtained (refer to as elements of the model).

\section{Rumah Cahaya's Profile}

Ms. Baiduri (not her real name) who owns and operates Rumah Cahaya (RC), was 27 years old and originally from Kuala Lumpur. She earned a Diploma in Culinary Arts with experience as a volunteer in various shelters that housed out of wedlock pregnant teenagers from 2013 to June 2019. At that time, she was also involved in helping out of wedlock pregnant teenagers in her own home without help from anyone or any party. However, after about six years, she decided to stop volunteering and give full attention to helping out of wedlock pregnant teens, set up the RC and registered its establishment in 2019. A high desire to help and perseverance prompted her to set up the shelter. According to her,

"I decided to set up this (RC) so that I can help more people. Before this, I did have a client like this (pregnant teenager) in my own home but then I could only have helped her alone until I decided to open my own shelter. So, I can help many more people."

\section{Establishment of Committees}

To facilitate with the management of the RC, the entrepreneur (Ms. Baiduri) had appointed a standing committee to assist her.

"The establishment of this house does have an organizational chart. This means that this house is indeed registered as an establishment. We don't have regular meetings, but I do meet with the treasurer and secretary."

\section{Psychosocial Support}

A counsellor was appointed RC to assist in the psychosocial aspects of its residents. According to her, 
DOI: https://doi.org/10.47405/aswj.v6i2.166

"Here we also provide registered counsellors to help the residents. Counsellors come here voluntarily; they will come according to their availability to be with the residents here. It is important because we want to help the residents in overcoming their problems, emotions and so on."

\section{Health Care}

Matters related to the health care of the residents were not neglected by the RC operator. There are certified nurses who help out on a voluntary basis.

"Yes, in this house there is a nurse from the paediatric ward. She helps voluntarily. Whenever there is a problem related to the baby she will come to help. She teaches the residents here about baby care and also the care of pregnant and postpartum mothers."

\section{Safety}

The safety aspect of every occupant in RC was also taken into consideration by Ms. Baiduri. She employs a warden to be responsible for looking after the security aspects and monitor the safety situations in the $\mathrm{RC}$ to prevent accidents or unwanted things from happening.

"We have a warden here, worried because in this house are all the teenage girls. For the safety of the occupants, babies, and even children. So, this warden will monitor what happens. We pay the warden salary, RM 600.00 per month."

\section{Financial Contribution}

The operator informed that RC has its own bank account. Many of Ms. Baiduri's friends had donated money to RC. Interestingly, his friends who contributed were not from the wealthy group. They often contacted her through social media to ask about the needs that they can contribute. Thus, this situation had helped in the sustainability of RC's expenditure.

"We have our own bank account. Donors are often among friends and through social media such as Facebook. But, mostly from friends. Friends are not rich people but the money they give us we can use to pay for utilities. Many items have never actually been purchased by me since the establishment of this house. Mostly are donations from friends. I never buy things like disposable diapers, baby milk, and rice because people will share. They usually will WhatsApp me once a month, asking about the needs of this house."

\section{Promotion and Announcement}

Ms. Baiduri's RC also received help from her friends to spread the word about the existence of RC to the community. They promoted RC via the social media. It is important that the community knows about the services provided by the RC to out of wedlock pregnant adolescents as well RC's needs to sustain its functions.

"I am lucky because I have friends from various fields. Some of them are well known in the community, so there will always be those who will help me in terms of spreading the words about this house, promote this house so that outsiders know the existence of this house." 
DOI: https://doi.org/10.47405/aswj.v6i2.166

\section{Sponsorship}

Ms. Baiduri was also grateful that RC is situated in a community whereby there are individuals who were willing to donate or sponsor food for the RC residents. Apart from fixed schedule of sponsorship of regular food by some individuals, other foods were also occasionally provided by other individuals in the community.

"Spending on this house does not cost a lot of money because sometimes every month there will be people who contribute something, especially food. There are individuals who regularly donate to us dishes from well-known food chains such as Kentucky Fried Chicken (KFC)."

\section{Entrepreneur Communication Skills}

According to Ms. Baiduri, communication skills are essential in the management of a shelter. Effective communication can make the public or at least the surrounding community aware of the existence of such shelters. Through communication, as stressed by Ms. Baiduri, it had also provided space and opportunities for outside individuals to provide assistance in the management of RC.

"I don't have a lot of problems [referring to the management of the Rumah Cahaya] because when we know how to talk to people, they will help us. This house really needs donations, so we have to communicate, to let people know."

\section{Appreciate People}

The RC operator showed concerned with the attitude of always appreciating any form of assistance provided by individuals. She always appreciated the people's contributions. She believed that such action will motivate a person to keep repeating contributing to RC.

"If we are not good at appreciating people who donated, maybe they will run away. When we know how to appreciate people, they will ask every month. What do you want? What is needed? What do you want this month? Fish? anchovies, once someone had send five kilos [of anchovies]."

\section{Knowledge and Skills}

Ms. Baiduri realized the importance of knowledge and skills. Although the residents of her shelter were going through social problems, she had strived to provide space and opportunities for their learning.

"I found the relevant teachers, then we paid based on the teacher's skills such as knitting, gardening and others. Things like that we will pay for. After all, we have money donated to the Rumah Cahaya. If the resident will sit for Sijil Pelajaran Malaysia (SPM), we do "home tuition". Apart from that, there are also residents that I will not allow to return home anymore, I want these residents to "home school" at least to get an SPM certificate."

\section{Relationship with Relatives}

The management of the RC was also assisted by some residents' parents or relatives who cared about the residents. Visiting residents was a highly encouraged activity because the practice can to some extent give strength and enthusiasm to the operator as well as to the residents. Ms. Baiduri had always strived to maintain good relations with the residents" parents or relatives. Incoming parents or relatives were not limited to those living near the RC only. In fact, there were even parents or relatives who came from 
locations far away from the RC. Some of them had also brought along with them various forms of donations.

"The families of the residents who came, sometimes ask what they [the residents] want. If they come, most of them will bring various things, maybe they feel happy that their children here are well taken care of. They came from different states, some from Pahang, Perak and so on. Some bring boxes of fruits such as durian, mangosteen and langsat. After all, I do not forbid them to come because they are the family of the residents here."

As noted earlier, the themes identified from the analysis of the interview were used as elements for the preliminary model of shelter management specifically for out of wedlock pregnant adolescents. The themes are (1) Establishment of Committees, (2) Psychosocial Support, (3) Health Care, (4) Safety, (5) Financial Contribution, (6) Promotion and Announcement, (7) Sponsorship, (8) Entrepreneur Communication Skills, (9) Appreciate People, (10) Knowledge and Skills, and (11) Relationship with Relatives. Figure 1.0 shows this model diagrammatically.

Figure 1: Preliminary model of shelter management

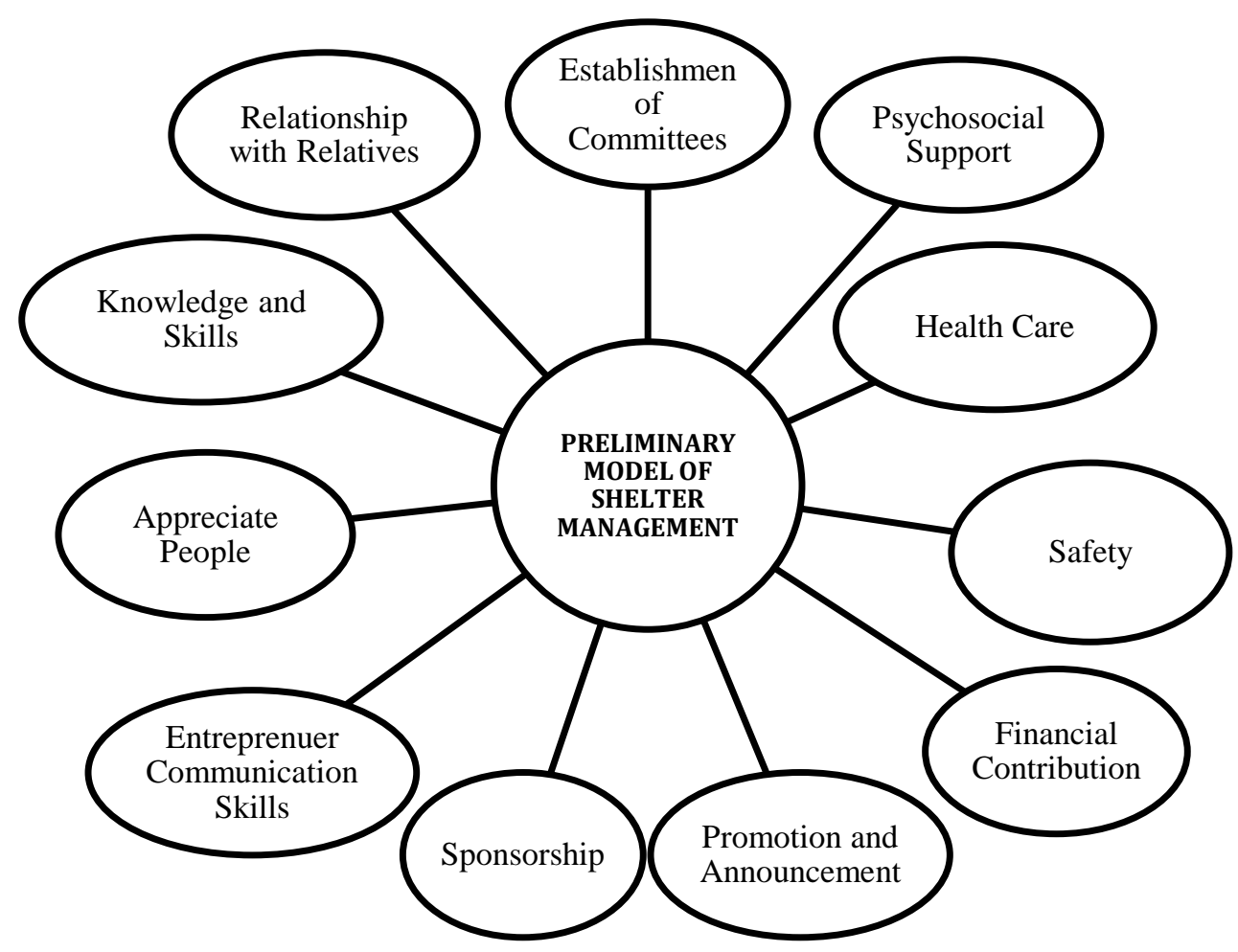

\section{Discussion}

Adolescents who are pregnant out of wedlock need to be given the attention by society regardless of their social class. Efforts towards curbing the spread of this social disease among female adolescents need to be stepped up, which include the construction of shelters for them. A house or shelter like this can be a suitable place where all activities and behaviours of the residents can be directly observed. These shelters can be managed by NGOs and the government by providing different support and services to out of wedlock pregnant adolescents. 
DOI: https://doi.org/10.47405/aswj.v6i2.166

This study focuses on one such house or shelter known as Rmah Cahaya (RC). In this study, we explored the hard work of the individual concerned who managed such a shelter from various angles as discussed in the results of the study. It is hoped that the results of this study with the initial or preliminary model for the management of a shelter can be used as a reference by the NGOs or any other organizations to strengthen their noble efforts in preparing youths with similar social problems to sustain their life in the future. Since this study looks at only one case, namely the RC shelter, the findings of this study cannot be generalized. However, the results of this study provide an initial idea of the management of such shelters for our society to help victims of illegal sex. We can learn from the operator's determination and sincerity in helping out of wedlock pregnant teenagers who are mostly ridiculed by society without investigating the real cause of the incidents. On the other hand, we too need to help these victims to live a normal life in the future. We can also provide support to the shelters' operators in terms of social support in the form of fund and psychology. RC seemingly is an example of a shelter that shows the mobilization of individual and community efforts to alleviate the psychosocial burden of the out of wedlock pregnant adolescents.

The preliminary model of shelter management contains 11 essential elements (refer to Figure 1.0) that are required by each operator to sustain his or her shelter management. Since every shelter needs to be registered and subject to the Care Centers (Amendment) Act (2006) (Nor Jana et al., 2013), this preliminary model is seen to help operators to better plan their shelter management and look after the welfare of the residents from various aspect. In addition, this preliminary model can also clarify the role of shelter operators who have a big responsibility and need to always think of ways to manage and sustain the financial viability of the shelters to continue their operations and intentions to help the out of wedlock pregnant teenagers who are looking for a place to get help.

Additionally, the preliminary model constructed can be used as a reference and input for the construction of a more robust shelter management model. In other words, this preliminary model can be used as a reference for the establishment of future shelters for out of wedlock pregnant teenagers. This preliminary model explains actions that can be considered good in terms of management, administration and management towards empowering and preparing the out of wedlock pregnant teenagers to manage their life in the future after going through their experience.

\section{Conclusion}

Interviews with shelter operators had provided input to enable us to construct a preliminary model of shelter management for out of wedlock pregnant adolescents. The results of the study found that the instinct to want to help and a possessing resilient heart are among the important characteristics that should be present to someone who wants to set up a shelter for adolescents who face social problems. Efforts to manage a shelter need to be given serious attention and high commitment in addition to a strong spirit and interest. The management of the shelters also needs the cooperation of the community or society to ensure its survival. They can provide social support in the form of money, goods, voluntary relief work and psychosocial support. Various methods to obtain external contributions can be made with the development of current technology.

The use of social media such as Facebook, Instagram, Twitter and other media can be utilized by entrepreneurs or operators for publicity purposes so that more people can contribute and support such noble projects. Entrepreneurs can use social networks such as, relatives, friends and acquaintances to also help manage residents in established shelters. The results of this study can also be used by those involved in the field of volunteerism and assistance to protect teenage mothers, especially those who are experiencing out of wedlock pregnancies.

\section{Acknowledgement}

This research was supported by Ministry of Higher Education through Fundamental Research Grant Scheme (FRGS/1/2018/SS06/UUM/02/6). 
DOI: https://doi.org/10.47405/aswj.v6i2.166

\section{References}

Aishah Mohd Nor, Najibah Mohd Zin, \& Roslina Che Soh. (2019). The adequacy of existing support systems in addressing the issue of teenage pregnancies in Malaysia: A legal response. International Islamic University Malaysia (IIUM) Law Journal, 27(1), 121-50. doi: 10.31436/iiumlj. v27i1.431

Azizi Yahaya, Yow Kiaw Geok, \& Amir Hamzah Abdul. (2008). Keberkesanan Program Pemulihan Akhlak di Sekolah Henry Gurney Tunas Bakti. Skudai: Universiti Teknologi Malaysia

Azmawaty Mohamad Nor, Shanina Sharatol Ahmad Shah, Usharani Balasingam, \& Zaida Nor Zainudin. (2019). The Turning Point in an Unwanted Teenage Pregnancy: A Psychoemotional Perspective. Malaysian Journal of Medicine and Health Sciences, 15. 30-36.

Babington, L. M., Malone, L., \& Kelley, B. R. (2015). Perceived social support, self-esteem, and pregnancy status among Dominican adolescents. Applied Nursing Research, 28 (2), 121-126.

Braun, V., \& Clarke, V. (2006) Using thematic analysis in psychology. Qualitative Research in Psychology, 3 (2), 77-101.

Cense, M., \& Ganzevoort, R. R. (2018): The storyscapes of teenage pregnancy. On morality, embodiment, and narrative agency. Journal of Youth Studies, 22(4), 568-583. doi: $10.1080 / 13676261.2018 .1526373$

Coleman, P. K. (2006). Resolution of unwanted pregnancy during adolescence through abortion versus childbirth: Individual and family predictors and psychological consequences. Journal Youth Adolescence, 35, 903-911.

Creswell, J. W. (2012). Qualitative inquiry and research design: Choosing among five approaches. Thousand Oaks, CA: Sage Publications.

Creswell, J. W., \& Creswell, J. D. (2018). Research design: Qualitative, quantitative and mixed methods approaches (5th ed.). Thousand Oaks, CA: Sage Publications.

Fatimah Abdullah (2009). Kisah hidup ibu tunggal dan anak tanpa nikah: Kajian kes di Kuala Lumpur. Paper presented at International Conference on Social Sciences and Humanities (ICOSH09), Universiti Kebangsaan Malaysia, Bangi, Malaysia.

Fauziah Mohd Sa'ad. (2014). Keberkesanan Kaunseling Kelompok Pendekatan Pemusatan Insan dan Pendekatan Psikologi Kognitif Ad-Din ke atas Konsep Kendiri, Kemurungan dan Daya Tahan Remaja Hamil Luar Nikah. (Doctoral dissertation). Universiti Kebangsaan Malaysia, Malaysia.

Fuziah Shaffie. (2016). Early child welfare policy and services in Colonial Malaya. International Review of Management and Marketing, 6(S8): 33-36.

Ghose, S., \& John, L. B. (2013). Obstetrics and psychosocial outcome of teenage pregnancy. Journal of Evolution of Medical and Dental Sciences, 2(45), 8745-8748.

Harlina Halizah Siraj (2014). Pengguguran: Sosial \& kesihatan [PowerPoint Slides]. Retrieved from http://www.infosihat.gov.my/

Hultstrand, J. N., Tydén, T., Jonsson, M., \& Målqvist, M. (2019). Contraception use and unplanned pregnancies in a peri-urban area of eSwatini (Swaziland). Sexual and Reproductive Healthcare, 20, 1-9. doi: 10.1016/j.srhc.2019.01.004

Khairul Hamimah Mohd Jodi, \& Nurul Husna Mansor. (2019). Kesediaan remaja hamil luar nikah terhadap program kerohanian di pusat perlindungan wanita. Islómiyyót 41(1), 59-68. doi: 10.17576/islamiyyat-2019-4001-06

Makiah Tussaripah Jamil, Abdul Mukti Baharudin, \& Hisam Satari. (2012). Pengguguran bayi menurut perspektif Islam dan perundangan di Malaysia. Global Journal Al-Thaqafah, 2(1), 69-82.

Malaysia Parliament. (2016, November 10). Pemberitahuan pertanyaan bagi jawapan lisan sidang dewan rakyat (soalan no. 16). Retrieved from https://pardocs.sinarproject.org

Marshall, C., \& Rossman, G. B. (2010). Designing qualitative research. Thousand Oaks, CA: Sage Publications.

Mohamad Faizal Mohammad \& Mohd Zaki Ishak. (2014). Gejala Hubungan Seks Dalam Kalangan Pelajar: Satu Kajian Kes. Proceedings at the National Seminar on Family Integrity, Faculty of Psychology and Education, Universiti Malaysia Sabah, Kota Kinabalu, Sabah.

Mohamad Shahbani \& Fuziah Shaffie (2020). Associated factors among unmarried pregnant adolescents in Malaysia. International Journal of Advanced Studies in Social Science and Innovation, 4(1): $1-15$. 
DOI: https://doi.org/10.47405/aswj.v6i2.166

Mohd Azis Ngah, (2010). 17,303 Anak Luar Nikah Didaftar 2009. Berita Harian Online. Retrieved from http://www.bharian.com.my

Mohd Hatta Abdul Mutalip, Kathryn Mishkin, Faizah Paiwai, Joanita Sulaiman, \& Norzawati Yoep (2019). Factors associated with sexual intercourse, condom-use, and perceived peer behaviors among adolescents in Malaysia: A school-based cross-sectional study. Malaysian Journal of Social Sciences and Humanities, 4(2), 8-18.

Nazni Noordin, Zaherawati Zakaria, Mohd Zool Hilmie Mohamed Sawal, Zaliha Hj Hussin, Kamarudin Ngah, \& Jennifah Nordin (2012). The voice of youngsters on baby dumping issues in Malaysia. International Journal of Trade, Economics and Finance, 3(1), 66.

Noor Hafizah binti Mohd Haridi. (2016). Program Agama Di Pusat Pemulihan Akhlak Jabatan Kebajikan Masyarakat (JKM): Kajian Dari Aspek Pelaksanaan Dan Keberkesanan. (Doctoral dissertation). Universiti Malaya, Malaysia.

Nor Jana Saim, Dufåker, M., Eriksson, M., \& Ghazinour, M. (2013). Listen to the voices of unwed teenage mothers in Malaysian shelter homes: An explorative study. Global Journal of Health Science, 5(5), 20-30. doi: 10.5539/gjhs. v5n5p20

Norhasmah Mohd Zain (2016). Outcomes of pregnancy among unmarried mothers in Malaysia. (Doctoral dissertation). Universiti Malaya, Malaysia.

Norul Huda Sarnon, Mohd Suhaimi Mohamad, Fauziah Ibrahim, Khadijah Alavi, Salina Nen, Suzana Mohd Hoesni, Zaizul Abdul Rahman, \& Wan Azreena Wan Jaafar. (2012). Hamil luar nikah: Memahami remaja sebagai asas intervensi keluarga. Jurnal Sains Sosial dan Kemanusiaan, 7(1), 121-130.

Nurul Husna Mansor, Khairul Hamimah Mohammad Jodi, Raihanah Abdullah, \& Fakhrul Adabi Abdul Kadir. (2017). Pemulihan Akhlak Di Pusat Perlindungan Wanita: Kajian Di Baitul Ehsan Dan Dar Assaadah. Jurnal Hadhari: An International Journal, 9(2), 261-274.

Patton, M. Q. (2002). Qualitative evaluation and research methods (3rd ed.). Newbury Park, CA: Sage. Polis Diraja Malaysia. (2016). Crime Cases Reported in Malaysia. Bukit Aman: Royal Malaysia Police. Pollock, A. (2016). Postpartum depression \& post-traumatic stress disorder. Retrieved from https://psychcentral.com/

Rohany Nasir, Zainah Ahmad Zamani, Rozainee Khairudin, Wan Shahrazad Wan Sulaiman, Mohd Norahim Mohd Sani \& Aizan Sofia Amin. (2016). Depression, loneliness and cognitive distortion among young unwed pregnant women in Malaysia: Counselling implications. Asian Social Science, 12(8), 104-109. doi:10.5539/ass. v12n8p104.

Santrock, J.W. 2008. Life-Span Development. 11th edition. Mc Graw-Hill; New York.

Sedgh, G., Finer, L. B., Bankole, A., Eilers, M. A., \& Singh, S. (2015). Adolescent pregnancy, birth, and abortion rates across countries: Levels and recent trends. Journal of Adolescent Health, 56(2), 223-230.

Sheela, A. M, Nair, M. K. C, \& Rema, S.D. (2013). Pregnancy among unmarried adolescents and young adults. Journal of Obstetrics and Gynaecology India, 63(1), 49-54.

Siti Marziah Zakaria \& Nur Afifah Binti Zulkifli. (2017). The Experience of Teens at Shelter Home and the Changes in the Meaning of Life. Journal of Social Sciences and Humanities, Special Issue 3.

Steinberg, L. 2007. Adolescence (8 ed.). New York: McGraw-Hill.

Vin, S. X., Muhammad, N. A., Sun, T. P., Meng, K. T. T., Tohid, H., \& Omar, K. (2014). Physical and psychosocial impacts of pregnancy on adolescents and their coping strategies: A descriptive study in Kuala Lumpur, Malaysia. Malaysian Journal of Public Health Medicine, 14(3), 71-80.

Wan Fadhilah Wan Ismail (2011, February 16). Kesan \& Akibat Kehamilan Remaja. MyHealth Ministry of Health Malaysia. Retrieved from http://www.myhealth.gov.my

Yahaya Mahamood, Nor Firdaos Mohamed, Normah Che Din dan Shah Ezzat Ghazali (2007). Berapa berat bahu masyarakat memikul berat lagi tanggungan ibu yang mengandungkan anak tanpa nikah: Satu tinjauan psikobiososial. Jurnal Psikologi dan Pembangunan Manusia, 23, 33-48.

Yin, R. K. (2003). Case study research: Design and methods (3rd ed.). London, England: Sage Publications. 